\title{
A Case of Bronchogenic Cyst with Infection of Paragonimus Westermani
}

\author{
Sang Baik Oh M. D.
}

Seoul Clinic, K. N. T. A.

\section{Introduction:}

Pulmonary cyst is a term which has been applied to a rather wide variety of pulmonary lesions characterized by the presence of air or fluid-containing spaces within the lung. Since the etiology, pathologic findings and clinical course may vary widely depending on specific features of the cystic lesion. Bronchogenic cyst is belong to the category of pulmonary cyst.

Bronchogenic cyst results from imperfect development of a brconchial bud. It contains fluid and has an epithelial lining. The lining contains mucous secreting glands; therefore the cyst tends to increase in size with age and may not be detected in childhood. It is smooth, oval, of homogenous density and lies in the mediastinum or lung. Most of the cyst is simple, and it is usually found behind the trachea or main bronchi. If the cyst connects with a bronchus there will be air with fluid level ${ }^{1}$.

Author experienced a case of congenital bronchogenic cyst with air-and fluid-containing cysts which was infected by paragonimus westermani. Since such a case is rarly seen author report the case.

\section{Case Report}

Case 1:
Kang. Y.A. 13 year old girl was admitted chest medicine dept. National Medical Center for diagnosis and treatment.

Family history was not contributory.

In past history she was admitted to a local hospital and was treated under the diagnosis of pleurisy with effusion at 2 occasions, 6 years and 3 years before admission.

6 months before admission patient got fever, cough and sputum and was treated with some drugs, resulted in subsidence of the symptoms. Similar episodes was repeated a few times.

Chest $\mathrm{x}$-ray taken 4 months before admission to our hospital, showed diffuse density in right mid. and lower lungfield and fluid levels in right lower lungfield so anti-tuberculous drugs were given for a month. On admission to our ward $(4 / 4 / 61)$ she was quite without marked symptoms except slight right chest pain, slight cough with purulent sputum. No bloody sputum or hemoptysis suggestive paragonimus infection was seen.

Physical examination: moderate development, moderate nourishement and healthy appearance. Pulse: 80, B.P. 115/75, temp. $37^{\circ} \mathrm{C}$ sclerae not icteric, conjunctive were not anemic. Tonsils were not enlarged. No lymphadenopathy, stiffness, nor thyroid swelling was seen on neck. Chest was symmetrically expanded. Heart examination was 
free. Chest had diminished breathing sound on right, slight dullness, rales on right mid. and lower post. portion. Abdomen was normal. Deep and superficial reflexies were all within normal limits. No clubbing fingers and toes were seen.

\section{Laboratory findings:}

Chest X-ray (plain) on $8 / 4 / 61$, as picture $1 \& 2$, showed diffuse homogenous density on right mid. lungfield, which was located in the post. part on the lateral view. Large cavity with 2 fluid levels are seen in the right basal field. SR $11 \mathrm{~mm} / \mathrm{h}$, Hgb. 15.3gm, WBC 7,900, differential count was and 9 , segment 45 , basophile 0 , eosinophile 7 , lymphocyte 3 4 , monocyte 5. RBC 5,3 million, urine test was SG 1,023, protein negative, sugar negative. Sputum test: TB smear negative on 6 occasions, TB culture negative on 5 occasions, paragonimus westermani negative on 2 occasions, malignant cell negative. Stool test: parasite negative. Mantoux test was positive weak.

After admission streptomycin, penicillin and INH were given daily. Some days after admission sudden high fever developed in spite of the antibiotics therapy, and the control X$\operatorname{ray}(8 / 22 / 63)$ shows that the pleural reaction in the right hemithorax has increased. Right lung temography $(8 / 23 / 63)$ shows shrunken lower lobe with compact density. Multiple cavities are seen in the basal part of the post. and ant. basal segments of the lower lobe. The middle lobe is slightly expanded posteriorly. Gland swelling in the hilum, pleural reaction is also seen in the anterior lateral part of the hemithorax. Paranasal sinus $\mathrm{X}$-ray showed no pathological findings. As temperature was rising up and to $38.5^{\circ} \mathrm{C}-39^{\circ} \mathrm{C}$ Medication was changed to chloramphenical $3 \mathrm{gm} / \mathrm{d}$ and sulfacombine $2 \mathrm{gm} / \mathrm{d}$ and postural drainage started.

Then the fever dropped down to normal step by step after 5 days. Sputum increased up to $10 \mathrm{cc}$ with distint foul odor only during the period of high fever.

Sputum culture for ordinary bacteria was reported as normal throat flora.

Since marked lung parenchymal change with probable co-existence empyema cavities, history of recurrent disease and possibility of further progression was aware of resectional therapy of right lung was planned to be done. As pre-operative check up bronchoscopy was performed, showing slight secretion coming out of right middle lobe opening and lower lobe bronchus and slightly narrow apical segment of lower lobe opening which was dislocated to the lateral side. Otherwise no pathology was visible.

Among the period of preoperative examination thoracenthesis was attempted on the right 6 th ICS mid-scapular line, obtaining 50 $\mathrm{ml}$ thick pus without noticeable foul smell.

This thoracentesis was performed at same place 3 cays later but no fluid was obtained. Further a week later the thoracenthesis was attempted again and that time 40cc of sticky thin bloody pus was hardly obtained. Exam. of the thick pus obtained by thoracenthesis was negative on culture of $T B$, fungus and ordinary bacteria.

Diagnosis was suspected congenital cyst or lung sequestration and coexistence empyema.

Operation was performed on 60 days of hospital day. The right lung was adherent to chest wall and diaphragm especially posterior lateral basal part of the lung. Upper and middles lobes looked intact. Lower lobectomy was performed. Postoperative course was uneventful.

Resected matreial was as follows: 

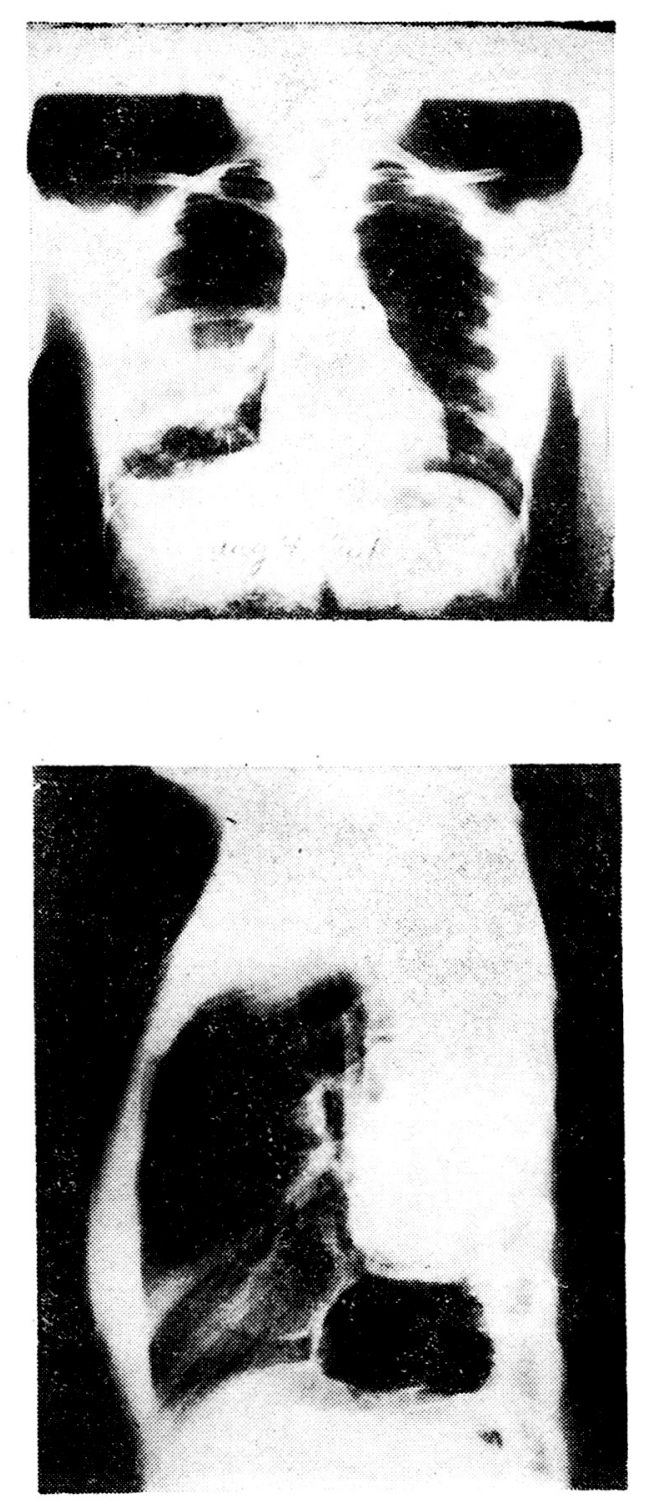

Macroscopically: Right lower lobe measuring $12 \times 12 \times 5 \mathrm{~cm}$., surface is overed fibrinous material. Consistency is irregular sized cystic changes. The largest one is measured $5 \times 5 \mathrm{~cm}$ and upper cystic lobe of lateral upper part which was the place that thoracentesis of a few times was performed, is contained dirty brown yellow red material and inner surface is granular with yellow brown color. The cyst
결핵 및 호흡기질환, Vol. 20, No. 4, October, 1973

of lower part shows smooth whitish and glistening inner surface containing clear fluid.

Both anterior and posterior part of the lung tissue is left unaffected without special changes. Sections are taken from upper part with cyst (I) lower part of cyst (II) normal looking lung perenchyma tissue (II). The cyst is communicated to the main bronchus.

Microscopically: I) One section shows many irregular sized cystic tissue with granulomatous inflammatory changes in the wall. There are many necrotic area, and in some area the surface of the cyst is lined by slightly atrophic bronchial epithelial cells. Some necrotic area, there are many eggs of paragonimus westermani, and some foreign body type giant cells. Interstitial fibrous tissue is well proliferated, and some bronchial lumen contains strains structureless material with some number of parahonimus westermani eggs. II) Many irregular sized cystic lumen with lining bronchial epithelial cells which are slightly atrophic. In the wall no cartilage, no mucous glands are seen but slightly infiltrated unspecific chronic inflammatory cells. There are no paragonimus eggs. II) Some scattered bronchial tissues are seen which are small and cystic places with alveoli. The alveoli shows some small empysematous areas with ruptured septa. There are no inflammatory changes and no other special findings, no paragonimus eggs.

Diagnosis was confirmed congenital cystic lung with infection of paragonimus westermani.

\section{Discussion :}

Bronchogenic cyst ${ }^{1)}$ results from imperfect development of a bronchial bud as previously mentioned.

The cysts being seen at fetus or new born baby is thought to be congenital but these cysts are also seen in child and adult. The 
cysts are classified into 3 types such as fluid filled cyst, tension cysts and infected cyst according to course of cysts $^{32}$ The fluid filled cyst is as follows: if the cyst remains with interception of bronchial connection, it is filled with fluid, fixed in size and has little symptoms. It is detected often accidently by $x$-ray exam. The tension cysts are formed by check value like mechanism occurs in narrow bronchial lumen after fluid is spitted out and when the communication between cyst and bronchus is incomplete. In consequence of enlargement of cyst compression signs and symptoms to adjoining tissues and organs are developed, namely mediastinal shifting giving rise respiratory and circulatory disturbance, among which the most characteristic symptome is that child begin to have cough and gradually become to dyspnea and cyanotic. Roentgenologically the cyst is shown clear margin and thin wall, and is one or some in number and located in a part of lung or occupying in entire lung, and decent of diaphra$\mathrm{gm}$, widening of intercostal space and mediastinal shift is seen.

Infected cysts: If fluid in cyst is drained out and connection with bronchus is relatively perfect, size of cyst become to be fixed and symptoms are not developed but these cysts are easily infected by bacteria. Tissue of cyst wall gives rise degenerative change gradually and in acute stage bronchitis and/or pneumonitis occurs. Symptom is in accordance with the degree of infection. Roentgenologicaly cyst margin is apparent, wall is thin, shape is round or oval, peripery has pneumonitis. Fluid level is seen sometimes, Cyst wall is thicker than that of tension cyst. This bronchogenic cyst should be differentiated from echinococcosis, primary and metastatic tumors, solitary lymphogranulomatosis, dermoid cyst, tuberculoma, encapsulated empyemas, pulmonary abscess, tuberculous cavity, diaphragmatic hernia, duplicated esophagus, bronchiectasis, circumscribed pneumothorax, acquired cyst (post-infectious pneumatocele) and nonspecific pneumonitis ${ }^{2)}$.

Postinfectious pneumatocele: In child postpneumonic pneumotoceles are representative but also this cyst can be produced at acute stage of staphylococcal pneumonia. Cyst is consisted of thin fibrous layer and no bronchial elements are mixed there, and it has tendency to disappear naturally. As the wall of cyst has no bronchial epithelium having secretory element, no secondary infection or accumulation of fluid is occured. When check value mechanism subsided the pneumotacele also disappear, resulting in showing normal lung tissue ${ }^{3)}$.

Acquired bronchiectasis and epitheliarized abscess cavity is one of the most difficult condition at differential diagnosis in some occasions clinically and histopathologically.

In bronchiectasis, even in the unusually huge cystic from bronchiectasis, histologically pseudostratified ciliated, columnar epithelium, which is seen in normal case, become to be cuboidal or flatten in case dilatation of bronchial wall occurs, and in most of cases inflammatory exsudate and granulation tissue replaces there more or less, and in majority elastic fiber of bronchus is shown the state with thickeness, even on naked eye.

Lung cysts in patients with bronchiectasis result from the course of pathological change of abscess of the bronchus. The alveolar cysts became expanded by the valular function of the alveoli or bronchus due to a bend or obstruction of the inducing bronchus or due to an imparment of tansition to the other bronchus. ${ }^{4)}$ 
Cystic bronchiectasis with minimal pathological change on the bronchial wall will be similar with bronchogenic cyst with slight inflammatory change, though in many of advanced bronchiectasis shows the typical picture in their histology. Then bronchogenic cysts principlly has no inflammatory process in the underlying tissue. Such a thing is seen principally at still born or newborn but the characteristic anatomy mentioned is destroyed when inflammatory process of infection intervene there during the growth and degeneration change on the cyst and on the surrounding tissue makes it uncertainly to be congenital and become more oi less similar to bronchiectasis. Therefore bronchozenic cyst and bronchiectasis is vice versa in their histopathological process. ${ }^{5)}$

The most accurate clinical diagnostic method is a through roentgenological examination (tomozraphy, bronchography, etc. $)^{6)}$.

Treatment should be removal of cyst which is radical therapy. Specially tension cysts should be done surgical resection which is only way of treatment, sometimes emergency treatment is necessary to save life, ${ }^{3)}{ }^{7)}$.

Author's case had a lining of slightly atrophic bronchial epithelial cells on the wall of both big cysts. The upper cyst contained dirty brownish yellow fluid and no bronchial communication existed there. Many paragonimus egges were seen in the necrotic part. Therefore we can think this is a bronchogenic cyst with paragonimiasis infection, though there is no absolute objection to that which necrotic change and granulamatus inflammatory change in the cyst wall and the abscence of bronchial communication was developed secondary to infection, specially by paragonimiasis and the large cystic change developed by check value mechanism in the course of
결핵 및 호흡기질환, Vol. 20, No. 4, October, 1973

the inflammation.

The lower cyst was communicated to the bronchus as shown in the bronchography.

Thus this cyst is thought to have played the part of infected cyst with the history of intermittent respiratory infections with asymptomatic intervals ${ }^{5)}$ ). The second case was a infected cyst covered by bronchial epithelium with bronchial communication and the surrounding part of cyst had slight inflammatory changes with bronchiectasis, and had a clinical manifestation of bronchial, chronic abscess syndrom and hemoptysis ${ }^{9}$, which is often seen in the case of infected cyst.

\section{References :}

1. Diseases of the chest, Hinshaw and Garland, Saunders Ltd. 1956.

2. Lung cyst- Tüdöcystäk esetei-Somogyi Z., Fejérm, Tanáes Kórháza, Szekesfehe rváza, Szekesfehe rvár-MAG. RADIOL: 1959, 11/1(3034)

3. Cystic disease of the lung, H. K. Lee, The Korean J. of Int. Med. Jan. 1962.

4. Pulmonary cyst(Japanese)-Kumagaya N. Tohoku Univ. Sch. of Med., Sendai-TOHOKU MED. J. 1961, 63/1-2(247-268)

5. Cystic cavities seen in 16 cases of lung diseases, H. S. Yoo and S. B. Oh, Tuberculosis and respiratory diseases, Vol 17, March 1964.

6. Pulmonary cysts: Their clinical and roentgenological diagnosis(Russian Text)-Bukhman A. I. VEST RENTGENOL: RADIO L. 1957, 32/4 (38 -45)

7. On pulmonary cyst- Tale P. Helsinki-ACTA CHIR. SCAND. 1957, 113/6 (536-540)

8. Bronchogenic cysts in Infants and children Herrmann J. W., Jewett Jr. T. C. and Galletti G. Dept. of Surg. Buffalo N. Y. -J. Thoracic Surg. 1969, 37/2(8242-8250)

9. Study of bronchogenic cysts(based on 23 cases) -Métras H., Laval P., Payan H., Longefait 
결핵 및 호홉기질환, Vol. 20, No. 4, October, 1973

H. and Girand-Michel-SUD. MED. CHIR. 1957, 90/2426(6734-6736)

10. 肺慗腫의 症例一咸聖淑, 결핵 및 호흡기질환, $\mathrm{Vol}$ 27, April 1967.

\section{〈國文抄錄 $>$}

\section{肺吸虫의 感染을 갖인 氣管枝性 桽連의 一例}

大韓結核協會 서울支部 附屬醫院

吳倘 伯

13歲 女兒로서 6個月間의 熱, 咳濑胸痛 및 喀痰의 主 訴로 國立醫療院 胸廓內科로 1963年 8月 20日에 入院하 였다. 6 年 및 3年前에 反復된 肋膜炎으로 個人病院에 入院한 病歷以外는 特記事項은 없었다. 入院時 診察所 見으로는 右側胸部後中肺野에서 呼吸音의 低下, dullness 및 rales等이 있었고, 胸部線 및 斷層寫眞에 작은 주
먹크기의 Compact density가 右肺下葉의 上區域을 占 하고 周囯肋膜肥厚를 同伴하고 있었고 그 바로 밑에 即 右肺下葉의 後半部에 多發性襄腫의 集團이 相互融合되어 ᄀ 內部低面에 水面陰影이 보였다. 其他理化學的檢查 結果에는 異常所見은 없었다, 反復한 喀痰結核菌, 肺吸 虫卵 및 癌細胞檢査는 全部 陰性이었다. 氣管枝鏡檢查에 는 小量의 分泌物이 右肺 中 및 下葉氣管枝孔에서 나오 고 있었고 右肺下葉의 上區域의 氣管分枝孔은 若干陝少 하게 보였다. 肋膜첨자를 右第六肋間 中扁胛骨線에서 施 行하여 $90 \mathrm{ml}$ 의 진한 血性膿을 吸出하였고 이 血性膿의 檢査에도 結核菌, fungus 또는 其他細菌은 發見하지 못했다. 先天性肺䔩腫 또는 lung sequestration의 假診 下에 右肺下葉切除述을 施行하였다. 適出한 右下葉의 肉 眼的所見은 크기는 $12 \times 12 \times 5 \mathrm{~cm}$ 이고 表面은 '纖維性組 䮺으로 皮包되었으며 內部에는 大小不規則한 크기의 襄 性變化를 일으키고 가장 큰 것은 $5 \times 5 \mathrm{~cm}$ 이었다. 顯微 鏡的 所見에는 어떤 露腫의 內壁에는 肉芽性炎症珄變化 또는 necrosis部分과 多數의 肺吸虫卵을 含有하며 이는 萎縮된 氣管上皮組織으로 된 小氣管枝와 連結되고 있었 고 다른 小唯胞內面은 上皮細胞로 被服되어 있었다. 以 上所見으로 氣管枝襄腫에 肺吸虫症이 感染된 것으로 確 定되며 여기에 報告한다. 